\title{
A Floresta e as Sêcas
}

368.55

Attilio Joffily

Derrotado, contemplou a propriedade em ruinas e abandonou-a num último esfôrço, levando a mulher e os três filhos pequenos.

De vila a vila, de cidade a cidade. errando, aturdido, sem saber em que ponto se deveria fixar, nasce-lhe e morre-lhe uma filha na passagem de Fortaleza, quando a Televisão Tupi o encontrou e trouxe-o a êle e a tamília ao Rio de Janeiro, para ser homenageado no programa «Esta é a sua vida».

Apresentado aos telespectadores do Canal 6, via-se-lhe, no olhar indiferente, o conhecido estigma da sêca.

A História registra e descreve com todos os horrores o martírio dos habitantes famintos de uma cidade sitiada. Lutando contra a sêca, sofre o sertanejo a mesma angústia, a mesma extenuação. $\cap$ mesmo desespêro, a mesma agonia dos cercos célebres das guerras antigas.

Desde a Colônia, da Colônia ao Império, do Império à República, desde as providências metropolitanas à declaração de D. PEDro II de que empenharia as jóias da coroa em benefício das vitimas de 1877, depois de mais de três séculos de calamidades periódicas no Brasil colônia, monarquista e republicano, caberia ao govêrno do Presidente Juscelino KubitsCHEK a execução de um plano de obras de combate às sêcas capaz de neutralizar os efeitos das estiagens nordestinas.

Açudes de construção projetada há dezenas de anos, como o de Orós, - fabuloso manancial de Orós, que terá cêrca de sessenta quilômetros de comprimento e volume de água maior que o da Baia da Guanabara, estarão concluídos até 1960, juntamente com as primeiras indústrias da chamada «Uperação Nordeste».

No setor da açudagem, Orós, o Banabuiu, o Castanheiro e o Araras, êste último de construção já terminada, represarão um volume d'água superior ao de todos os açudes construídos no Nordeste durante o Império e, na República, até o ano de 1955.

Em Pernambuco, na sêca de 1932, vimos em casa de numerosas e miserável fámília sertaneja, quando cuidava fugir do exterminio, arrumando mochilas, bisacos e matolóes, um menino de uns dois anos, deitado de bruços, no chão, com um envoltório de pano grosso comprimindo-lhe o estômago. 
Entendida nessa posição, o próprio corpinho mirrado protegendo a da ânsia da tome, a pobre criança dormia profundamente. Na soleira da porta, uma cabra leiteira, de ubre murcho, caída exânime, animava êste quadro de cenas da sêca.

Eis o calvário secular dos oito Estados mártires da Federação.

A primeira sêca que as crônicas registraram, di-lo Pereira DA Costa, o mais insigne dos historiadores do Nordeste, nos seus «Anais Pernambucanos», foi a de 1582. Iniciara-se o ciclo negro das estiagens nordestinas.

A aproximação do cataclismo, as populações, aterrorizadas e isoladas no recesso do sertão, ganhavam o litoral, distante centenas de quilômetros, em marchas forçadas como um «rush» trágico, «morrendo pelos caminhos à fome, e pelas matas, muitas mulheres, meninos e gente mais fraca».

IRENÊO JOFFILY, nas suas «Notas sôbre a Paraiba», publicadas em 1892, antevendo uma derivação do S. Francisco para os vales do Piranhas e Jaguaribe, apontando o valor do aproveitamento dos boqueirões da Borborema, mostrando a necessidade da criação de um serviço especial de açudes para seu Estado, alonga-se em considerações judiciosas sôbre a devastação das matas e a sua influência na calamidade das sêcas.

Citando os altaneiros jatobás, pitiás, louros, feijós e outras árvores fron dosas que circundavam a antiga povoação de Pocinhos, hoje um dos municípios mais secos do agreste paraibano, assim conclui o historiógrafo de Campina Grande: «Havia pois no solo uma certa frescura; do contrário não se dariam bem ali aquelas espécies vegetais. Depois essas árvores foram pouco a pouco destruidas, ficando, afinal, completamente descobertas as imensas rochas que, recebendo diretamente os raios solares, refletem-nos poderosamente nos terrenos adjacentes; e o resultado foi e é que essa povoação tornou-se tão diferente de clima, que ainda nos invernos regulares conta com poucas chuvas». «No Ceará», escreve o senador POMPEU, «é fato constantemente observado que nas regiões ou tratos de terrenos mais secos e rochosos da provincia é onde chove mais tarde e menos».

Concluiamos êstes comentários, quando deparamos no «Correio da Manhã», de 27 de julho último, a notícia sob a epigrafe: «Navarro Sampaio e o problema florestal». Em entrevista ao grande jornal, que vem desenvolvendo meritória campanha em prol do reflorestamento, o engenheiro-agrônomo Armando Navarro Sampaio declarou que «A derrubada das matas em nada influi para criar ou aumentar a sêca em parte alguma do mundo», e que «As florestas têm pouca ou nenhuma influência sôbre a precipitação».

Aceita a tese do ilustre diretor do Serviço Florestal da Companhia Paulista de Estradas de Ferro, estaria deformado o plano do conjunto das Obras contra as sêcas, numa das suas partes mais essenciais - o reflorestamento. À continuidade dêsses serviços, verbas seriam negadas ao reflorestamento do Nordeste em pareceres firmados nos conceitos da maior autoridade do País em silvicultura.

Não temos estudos profissionais para opor contradita às afirmações do engenheiro-agrônomo Navarro Sampaio, nem passaremos do calçado. Contradita, quem a opõe, formalmente, é próprio entrevistado do «Correio da Manhã», quando acrescentou à sua entrevista que «As raizes das árvores 
das matas servem de drenos para condução das águas das chuvas às camadas mais profundas do solo, dirigindo-se até aos vales onde vão alimentar as nascentes», e que «Presta a floresta serviços inestimáveis como elemento controlador do regime das águas dos rios».

Nestas palavras retificadoras, o eminente engenheiro agrônomo reco nhece e expressa o valor da floresta como anteparo poderoso ao flagelo das sêcas nordestinas.

Riachos e ribeiros inumeráveis correram perenes em todo o Nordeste até o dia em que, destruídas as matas que lhes alimentavam as nascentes, desapareceram-lhes as águas e integraram-se à desolação da paisagem sertaneja.

Se «A derrubada das matas em nada influi para criar ou aumentar a sêca em parte alguma do mundo», e, se «As florestas têm pouca ou nenhuma influência sôbre a precipitação», certamente êsses riachos e ribeiros teriam se mantido.

Entretanto, o que se viu foi o contrário. Sem o concurso das árvores que lhes guarneciam as cabeceiras, estancaram-se e confundiram-se-lhes os leitos secos com a aridez das terras vizinhas.

As «Notas sôbre a Paraiba» registram os nomes e os municipios de vários dêsses riachos e ribeiros de águas cortadas à destruição das matas que lhes cobriam as fontes:

«O ribeiro Goiacu (municipio de Catolé do Rocha) já foi perene, hoje corre somente durante os invernos abundantes, o que foi motivado pela derrubada da mata que cobria o ôlho d'água donde sai».

A êste respeito, referindo se à sêca de 1853, PEREIRA DA Costa menciona nos seus «Anais» um ofício em que o gabinete do Império pedia ao Govêrno de Pernambuco informações sôbre as causas das sêcas repetidas que assolavam aquela região.

Particularizando o que responderam sôbre o assunto as Câmaras Municipais de Caruaru, Nazaré, Bonito, Bezerros, Gravatá, Brejo, Boa Vista, Flôres, Cimbres e Tacaratu, conclui o autor do trabalho sôbre a elaboração de um Código Florestal, apresentado à Conferência Açucareira do Recife, em 1905, dizendo que as aludidas Câmaras «foram unânimes em manifestar como as suas causas eficientes a derrubada e fogo das matas, principalmente às margens dos rios, pedindo como meio de remediá-las a construção de açudes e o plantio de grandes árvores nas situações devastadas, e muito particularmente às margens dos rios e ribeiros e cabeceiras das fontes».

Sôbre os serviços inestimáveis da floresta como «elemento controlador do regime das águas dos rios», revela ainda o mesmo autor trechos de um relatório do engenheiro Luís LEGER WAUTHIER, apresentado ao Govêrno de Pernambuco, em 1841, dos quais, por mais expressivo, transcrevemos o seguinte:

«À falta de matas às margens do Capibaribe e Ipojuca, vem a escassez dêsses rios pelo verão e as grandes cheias que sofrem pelo inverno; e que pelas mesmas se originam, mais generalizadas, nesta e nas provincias limitrofes, as grandes e repetidas secas que assolam esta parte do pais.» 
Quem lê os «Anais Pernambucanos», essa obra monumental, de 12 volumes, de cêrca de 500 páginas cada um, cuja publicação, já no $66^{\circ}$ tomo, vem sendo feita por iniciativa do Govêrno de Pernambuco, verifica que o ciclo das sêcas coincide com o das derrubadas.

Decorridos 27 anos da sêca de 1522, uma carta régia de 1609 proibia o corte de árvores «porquanto em algumas capitanias havia muita falta de lenha e madeiras e pelo tempo adiante haveria muito maior».

No Nordeste, a destruição das florestas em tudo aparece criando ou aumentando a sêca.

Os «Anais Pernambucanos» consignam uma infinidade de decretos e alvarás proibitivos da devastação das matas.

À continuação das derrubadas, a carta régia de 17 de março de 1796 criava uma nova magistratura no Brasil com o título de «Juiz conservador das Matas», "para cuja incumbência teve um regimento especial».

Malogradas tôdas essas providências na ação intangivel dos derrubadores, na ação aniquiladora do fogo e do machado abrindo clareiras na mataria densa, foi-se ampliando a área das secas nesse delito dos séculos, até abranger as proporções colossais dos nossos dias.

Que os bispos e vigários do Nordeste, com a sua autoridade moral, fôrça espiritual e poder moderador às tradicionais lutas politicas e de famílias dessa região das sêcas, se não omitam à campanha do reflorestamento, que se desenvolve em todo o País sob os auspícios do Ministério da Agricultura.

Que o nosso admirável Dom Helder CÂmara, nordestino cearense, dê uma palavra sôbre o assunto.

Que ềsses bispos e vigários promovam por todos os meios de que são capazes, através de Foros Econômicos e Sociais, instalados permanentemente em cada municipio, um passo notável à vitória do Municipalismo Brasileiro, o reflorestamento das cabeceiras das fontes de tôdas as cidades, vilas e distritos das suas dioceses e paróquias, e, que, em todo quintal dessas cidades, vilas e distritos, se plante um jatobá ou uma aroeira, um pitiá ou um caraibeira, um loureiro ou uma sicupira, uma árvore qualquer de grande porte. 